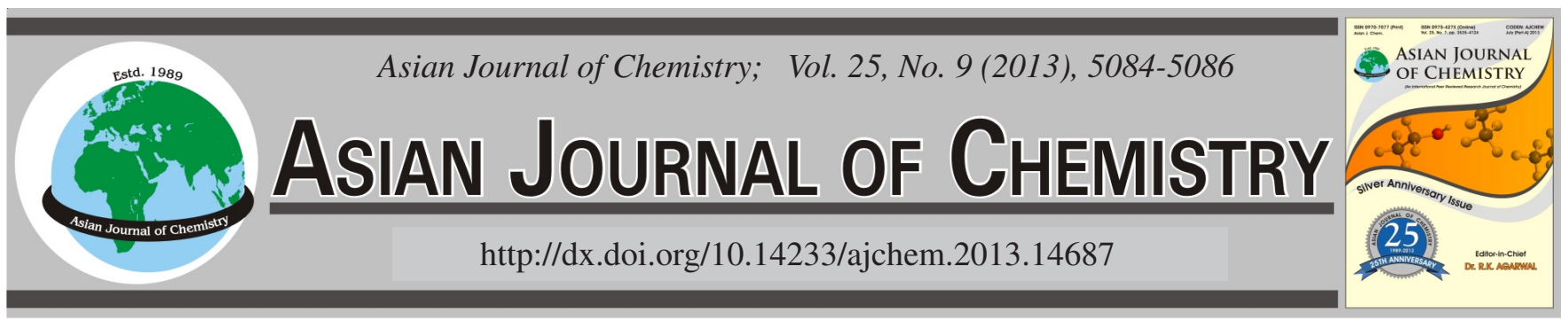

\title{
Synthesis and Structural Characterization of Copper(II) Complex with Asymmetrical Salen-Type Bisoxime Ligand
}

\author{
Wen-You Li ${ }^{1, *}$, Yu-Jie Zhang ${ }^{2}$, XIU-YAn Dong ${ }^{2}, \mathrm{XIANG}_{\mathrm{LI}}{ }^{2}$ and $\mathrm{Li}_{\mathrm{WANG}}{ }^{2}$
}

${ }^{1}$ Department of Chemical Engineering, Jiuquan Vacational and Technical College, Jiuquan 735009, P.R. China

${ }^{2}$ School of Chemical and Biological Engineering, Lanzhou Jiaotong University, Lanzhou 730070, P.R. China

*Corresponding author: E-mail: wenyoulijq@126.com

(Received: 16 October 2012;

Accepted: 20 March 2013)

AJC-13143

\begin{abstract}
A new mononuclear $\mathrm{Cu}$ (II) complex, $[\mathrm{CuL}]$, has been synthesized by the reaction of copper(II) acetate tetrahydrate with $\mathrm{H}_{2} \mathrm{~L}\left(\mathrm{H}_{2} \mathrm{~L}=\right.$ 4-bromo-6'-methoxy-2,2'-[ethylenediyldioxybis(nitrilomethylidyne)]diphenol). X-Ray crystallographic analysis reveals that the complex crystallizes in the monoclinic system, space group P2(1) and the unit cell contains two crystallographically independent but chemically

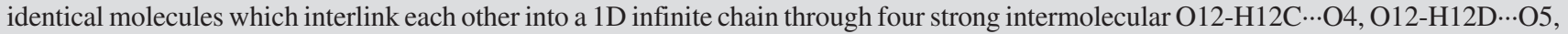

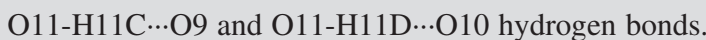

Key Words: Copper(II) complex, Asymmetrical bisoxime ligand, Synthesis, Crystal structure.

\section{INTRODUCTION}

Salen-type ligand and its derivatives which contain $\mathrm{N}_{2} \mathrm{O}_{2}$ site are easily coordinated to $d$-block transition metals in a tetradentate fashion to afford stable mononuclear complexes ${ }^{1,2}$. Consequently, increasing interest has been focused on their potential applications, such as near infrared chiroptical sensors ${ }^{3}$, single-source precursors for metal-organic chemical vapor deposition (MOCVD) $)^{4}$, metallomesogens ${ }^{5}$, interesting magnetic properties ${ }^{6-8}$ and so forth. Further, synthesizing unsymmetrical salen derivatives, which consist of two different salicylideneimine moieties, is much more difficult because a statistical mixture of three possible condensation products is usually obtained ${ }^{9}$. However, our team has synthesized several refined chiral unsymmetrical salen-type bisoxime ligands and obtained their copper(II) complexes. Herein, we report the synthesis and crystal structure of a copper(II) complex with an asymmetrical bisoxime ligand $\left[\mathrm{H}_{2} \mathrm{~L}\right]$, 4-bromo-6-methoxy2,2'-[ethylenediyldioxybis(nitrilomethylidyne)] diphenol.

\section{EXPERIMENTAL}

5-Bromosalicylaldehyde and 2-hydroxy-3-methoxybenzaldehyde from Aldrich were used without further purification. The other reagents and solvents were analytical grade reagents from Tianjin Chemical Reagent Factory. C, H and N analyses were carried out with a GmbH VariuoEL V3.00 automatic elemental analyzer. X-ray single crystal structure was determined on a Bruker Smart 1000 CCD area detector.
Melting points were measured by the use of a microscopic melting point apparatus made in Beijing Taike Instrument Limited Company and the thermometer was uncorrected.

Preparation of $\mathbf{H}_{2} \mathbf{L}$ : 1,2-Bis(aminooxy)ethane was synthesized by a similar method ${ }^{10}$. Yield, $52.7 \%$. Anal. calcd. (\%) for $\mathrm{C}_{2} \mathrm{H}_{8} \mathrm{~N}_{2} \mathrm{O}_{2}: \mathrm{C}, 26.08 ; \mathrm{H}, 8.76 ; \mathrm{N}, 30.42$. Found (\%): C, 25.92; H, 8.87; N, 30.39.

4-Bromo-6-methoxy-2,2'-[ethylenediyldioxybis (nitrilomethylidyne)]diphenol $\left(\mathrm{H}_{2} \mathrm{~L}\right)$ was synthesized as follows: Firstly, synthesis for mono-oxime, a solution of 1,2-bis(aminooxy)ethane $(1749 \mathrm{mg}, 19 \mathrm{mmol})$ in ethanol $(70 \mathrm{~mL})$ was added to a solution of 2-hydroxy-3-methoxybenzaldehyde (1489 mg, $10 \mathrm{mmol})$ in ethanol $(40 \mathrm{~mL})$ and the mixture was stirred at 326-328 $\mathrm{K}$ for $4 \mathrm{~h}$. The solution was concentrated in vacuo and the residue was purified by column chromatography $\left(\mathrm{SiO}_{2}\right.$, chloroform/ethyl acetate, 20:1) to afford $941 \mathrm{mg}$ colourless crystals of monooxime compound. Yield, $52.0 \%$, m.p 367$368 \mathrm{~K}$. Analysis for $\mathrm{C}_{10} \mathrm{H}_{14} \mathrm{~N}_{2} \mathrm{O}_{4}$ (226.23): calcd. (\%) C, 53.09; H, 6.24; N, 12.38. Found (\%): C, 52.94; H, 6.31; N, 12.32 .

Then, a solution of the obtained monooxime $(430 \mathrm{mg}$, $1.9 \mathrm{mmol})$ in ethanol $(30 \mathrm{~mL})$ was added to a solution of 5-bromosalicylaldehyde $(385 \mathrm{mg}, 1.9 \mathrm{mmol})$ in ethanol $(20$ $\mathrm{mL}$ ) and the mixture was stirred at 328-333 K for $6 \mathrm{~h}$. The formed precipitate was separated by filtration and washed successively with ethanol and $n$-hexane. The product was dried under vacuum to yield $0.6253 \mathrm{~g}$ of the $\mathrm{H}_{2} \mathrm{~L}$ yield, $80.38 \%$, mp. 381-382 K. Anal. calcd. (\%) for $\mathrm{C}_{17} \mathrm{H}_{17} \mathrm{~N}_{2} \mathrm{O}_{5} \mathrm{Br}$ : C, 49.89; H, 4.19; N, 6.85. Found (\%): C, 49.92; H, 21; N 6.77. 


\begin{tabular}{ll}
\hline & \multicolumn{1}{c}{ TABLE-1 } \\
\multicolumn{1}{c}{ CRYSTAL DATA AND STRUCTURE } \\
\multicolumn{1}{c}{ REFINEMENT FOR THE COMPLEX } \\
\hline Empirical formula & $\mathrm{C}_{17} \mathrm{H}_{17} \mathrm{BrCuN}_{2} \mathrm{O}_{6}$ \\
Formula weight & 488.78 \\
Temperature $(\mathrm{K})$ & $298(2)$ \\
Wavelength $(\AA)$ & 0.71073 \\
Crystal system & Monoclinic \\
Space group & $\mathrm{P} 2(1)$ \\
Cell dimensions, $\left(\AA{ }^{\circ}{ }^{\circ}\right)$ & $\mathrm{a}=13.9529(14), \mathrm{b}=7.6135(7)$, \\
& $\mathrm{c}=18.5996(17), \beta=109.716(2)$ \\
Volume $\left(\AA^{3}\right)$ & $1860.0(3)$ \\
$\mathrm{Z}$ & 4 \\
Density (calculated) $\left(\mathrm{mg} / \mathrm{m}^{3}\right)$ & 1.745 \\
Absorption coefficient $\left(\mathrm{mm}^{-1}\right)$ & 3.359 \\
$\mathrm{~F}_{\text {(000) }}$ & 980 \\
Index ranges & $-16 \leq \mathrm{h} \leq 16,-8 \leq \mathrm{k} \leq 9,-22 \leq 1 \leq$ \\
& 13 \\
Reflections collected & $8122 / 5636\left[\mathrm{R}_{(\mathrm{int})}=0.0913\right]$ \\
Independent reflections & 2253 \\
Data/restraints/parameters & $5636 / 0 / 490$ \\
Goodness of fit indicator & 1.196 \\
$\mathrm{R}[\mathrm{I}>2 \sigma(\mathrm{I})]$ & $\mathrm{R}_{1}=0.0585, \mathrm{wR}_{2}=0.0950$ \\
Largest diff. peak and hole $\left(\mathrm{e} \AA^{-3}\right)$ & 0.816 and -0.869 \\
\hline
\end{tabular}

Synthesis of $\mathbf{C u}(\mathrm{II})$ complex: A solution of copper(II) acetate hydrate $(2.1 \mathrm{mg}, 0.11 \mathrm{mmol})$ in ethanol $(2 \mathrm{~mL})$ was added dropwise to a solution of $\mathrm{H}_{2} \mathrm{~L}(5.3 \mathrm{mg}, 0.13 \mathrm{mmol})$ in ethanol $(2 \mathrm{~mL})$ at room temperature. The colour of the mixing solution turned to brown immediately, the mixture was filtered and the filtrate was allowed to stand at room temperature for about three weeks. The solvent was partially evaporated and several pale-brown needle-like single crystals suitable for $\mathrm{X}$-ray crystallographic analysis were obtained.

$\mathbf{X}$-Ray structure determination: The single crystal of the title compound, with approximate dimensions of $0.46 \mathrm{~mm}$ $\times 0.30 \mathrm{~mm} \times 0.07 \mathrm{~mm}$ was placed on a Bruker Smart 1000 diffractmeter equipped with Apex CCD area detector. The diffraction data were collected using a graphite monochromated $\operatorname{MoK}_{\alpha}$ radition $(\lambda=0.71073 \AA)$ at $298(2) \mathrm{K}$. The structure was solved by using the program SHELXS-97 and Fourier difference techniques and refined by full-matrix least-squares method on $\mathrm{F}^{2}$ using SHELXL-97. Details of the data collection and refinements of the title compound are given in Table-1. The non-hydrogen atoms were refined anisotropically. Hydrogen atoms were added theoretically. CCDC: 896948.

\section{RESULTS AND DISCUSSION}

X-Ray crystallographic analysis revealed the crystal structure of the $\mathrm{Cu}(\mathrm{II})$ complex. And the structure is shown in Fig. 1. Selected bond distances and angles are listed in Table-2. The complex crystallizes in the monoclinic system, space group $\mathrm{P}(2) 1$ and the unit cell contains two crystallographically independent but chemically identical molecules (molecules A and B, Fig. 1). And the dihedral angle of the two benzene rings (C4-C9 and $\mathrm{C} 12-\mathrm{C} 17)$ in the molecule $\mathrm{A}$ is $51.76(3)^{\circ}$, while it is $55.34(3)^{\circ}(\mathrm{C} 21-\mathrm{C} 26$ and $\mathrm{C} 29-\mathrm{C} 34)$ in the molecule B.

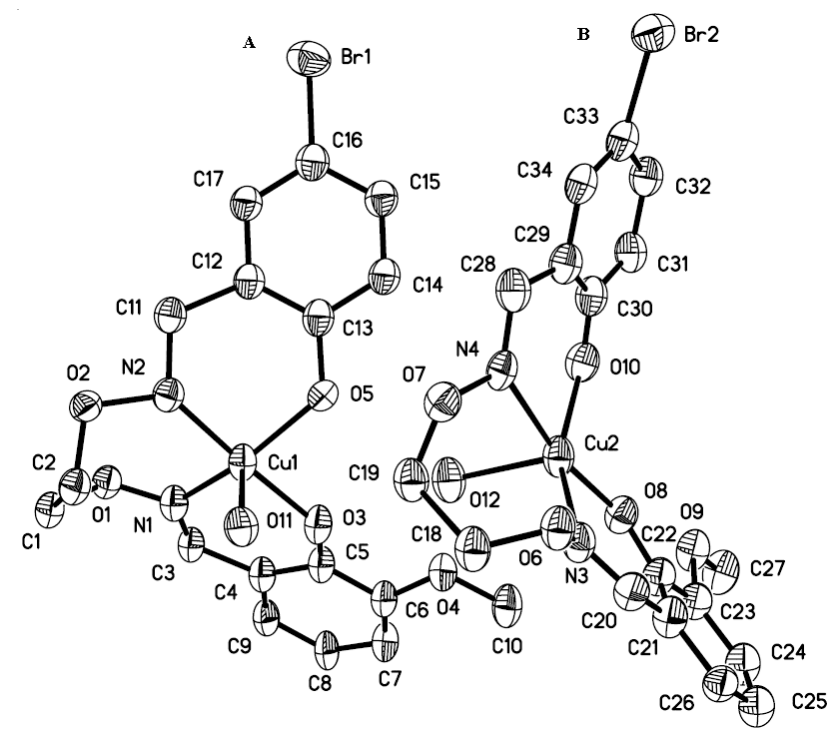

Fig. 1. Molecule structure of the complex with atom numbering scheme. Displacement ellipsoids for non- $\mathrm{H}$ atoms are drawn at the $30 \%$ probability level

\begin{tabular}{|c|c|c|c|c|c|}
\hline \multicolumn{6}{|c|}{$\begin{array}{c}\text { TABLE-2 } \\
\text { SELECTED BOND DISTANCES }(\AA) \text { AND ANGLES }\left({ }^{\circ}\right) \text { FOR THE COMPLEX }\end{array}$} \\
\hline Bond & Lengths & Bond & Lengths & Bond & Lengths \\
\hline $\mathrm{Cu}(1)-\mathrm{N}(2)$ & $1.88(3)$ & $\mathrm{Br}(2)-\mathrm{C}(33)$ & $1.90(4)$ & $\mathrm{O}(3)-\mathrm{C}(5)$ & $1.32(4)$ \\
\hline $\mathrm{Cu}(1)-\mathrm{O}(3)$ & $1.93(3)$ & $\mathrm{N}(1)-\mathrm{C}(3)$ & $1.25(4)$ & $\mathrm{O}(4)-\mathrm{C}(6)$ & $1.38(4)$ \\
\hline $\mathrm{Cu}(1)-\mathrm{O}(5)$ & $1.93(2)$ & $\mathrm{N}(1)-\mathrm{O}(1)$ & $1.32(4)$ & $\mathrm{O}(4)-\mathrm{C}(10)$ & $1.41(4)$ \\
\hline $\mathrm{Cu}(1)-\mathrm{N}(1)$ & $2.00(3)$ & $\mathrm{N}(2)-\mathrm{C}(11)$ & $1.41(4)$ & $\mathrm{O}(5)-\mathrm{C}(13)$ & $1.39(4)$ \\
\hline $\mathrm{Cu}(1)-\mathrm{O}(11)$ & $2.23(2)$ & $\mathrm{N}(2)-\mathrm{O}(2)$ & $1.48(4)$ & $\mathrm{O}(6)-\mathrm{C}(18)$ & $1.41(5)$ \\
\hline $\mathrm{Cu}(2)-\mathrm{O}(8)$ & $1.91(2)$ & $\mathrm{N}(3)-\mathrm{C}(20)$ & $1.21(4)$ & $\mathrm{O}(7)-\mathrm{C}(19)$ & $1.40(4)$ \\
\hline $\mathrm{Cu}(2)-\mathrm{N}(3)$ & $2.07(3)$ & $\mathrm{N}(3)-\mathrm{O}(6)$ & $1.32(4)$ & $\mathrm{O}(8)-\mathrm{C}(22)$ & $1.26(4)$ \\
\hline $\mathrm{Cu}(2)-\mathrm{O}(10)$ & 2.09(3) & $\mathrm{N}(4)-\mathrm{C}(28)$ & $1.34(5)$ & $\mathrm{O}(9)-\mathrm{C}(27)$ & $1.32(4)$ \\
\hline $\mathrm{Cu}(2)-\mathrm{N}(4)$ & $2.17(3)$ & $\mathrm{N}(4)-\mathrm{O}(7)$ & $1.43(4)$ & $\mathrm{O}(9)-\mathrm{C}(23)$ & $1.52(4)$ \\
\hline $\mathrm{Cu}(2)-\mathrm{O}(12)$ & $2.25(2)$ & $\mathrm{O}(1)-\mathrm{C}(1)$ & $1.45(5)$ & $\mathrm{O}(10)-\mathrm{C}(30)$ & $1.22(4)$ \\
\hline $\mathrm{Br}(1)-\mathrm{C}(16)$ & $1.89(4)$ & $\mathrm{O}(2)-\mathrm{C}(2)$ & $1.42(4)$ & - & - \\
\hline Bond & Angles & Bond & Angles & Bond & Angles \\
\hline $\mathrm{N}(2)-\mathrm{Cu}(1)-\mathrm{O}(3)$ & $176.6(13)$ & $\mathrm{O}(3)-\mathrm{Cu}(1)-\mathrm{O}(11)$ & $91.9(10)$ & $\mathrm{N}(3)-\mathrm{Cu}(2)-\mathrm{N}(4)$ & $94.5(11)$ \\
\hline $\mathrm{N}(2)-\mathrm{Cu}(1)-\mathrm{O}(5)$ & $92.0(11)$ & $\mathrm{O}(5)-\mathrm{Cu}(1)-\mathrm{O}(11)$ & $94.6(9)$ & $\mathrm{O}(10)-\mathrm{Cu}(2)-\mathrm{N}(4)$ & $84.9(11)$ \\
\hline $\mathrm{O}(3)-\mathrm{Cu}(1)-\mathrm{O}(5)$ & $86.0(10)$ & $\mathrm{N}(1)-\mathrm{Cu}(1)-\mathrm{O}(11)$ & $113.4(11)$ & $\mathrm{O}(8)-\mathrm{Cu}(2)-\mathrm{O}(12)$ & $96.2(10)$ \\
\hline $\mathrm{N}(2)-\mathrm{Cu}(1)-\mathrm{N}(1)$ & $91.4(12)$ & $\mathrm{O}(8)-\mathrm{Cu}(2)-\mathrm{N}(3)$ & $88.6(11)$ & $\mathrm{N}(3)-\mathrm{Cu}(2)-\mathrm{O}(12)$ & $110.5(11)$ \\
\hline $\mathrm{O}(3)-\mathrm{Cu}(1)-\mathrm{N}(1)$ & $89.1(11)$ & $\mathrm{O}(8)-\mathrm{Cu}(2)-\mathrm{O}(10)$ & $88.0(10)$ & $\mathrm{O}(10)-\mathrm{Cu}(2)-\mathrm{O}(12)$ & $93.1(10)$ \\
\hline $\mathrm{O}(5)-\mathrm{Cu}(1)-\mathrm{N}(1)$ & $151.7(11)$ & $\mathrm{N}(3)-\mathrm{Cu}(2)-\mathrm{O}(10)$ & $156.3(11)$ & $\mathrm{N}(4)-\mathrm{Cu}(2)-\mathrm{O}(12)$ & $92.6(10)$ \\
\hline $\mathrm{N}(2)-\mathrm{Cu}(1)-\mathrm{O}(11)$ & $91.0(10)$ & $\mathrm{O}(8)-\mathrm{Cu}(2)-\mathrm{N}(4)$ & $169.0(12)$ & $\mathrm{C}(5)-\mathrm{O}(3)-\mathrm{Cu}(1)$ & $122.4(5)$ \\
\hline
\end{tabular}




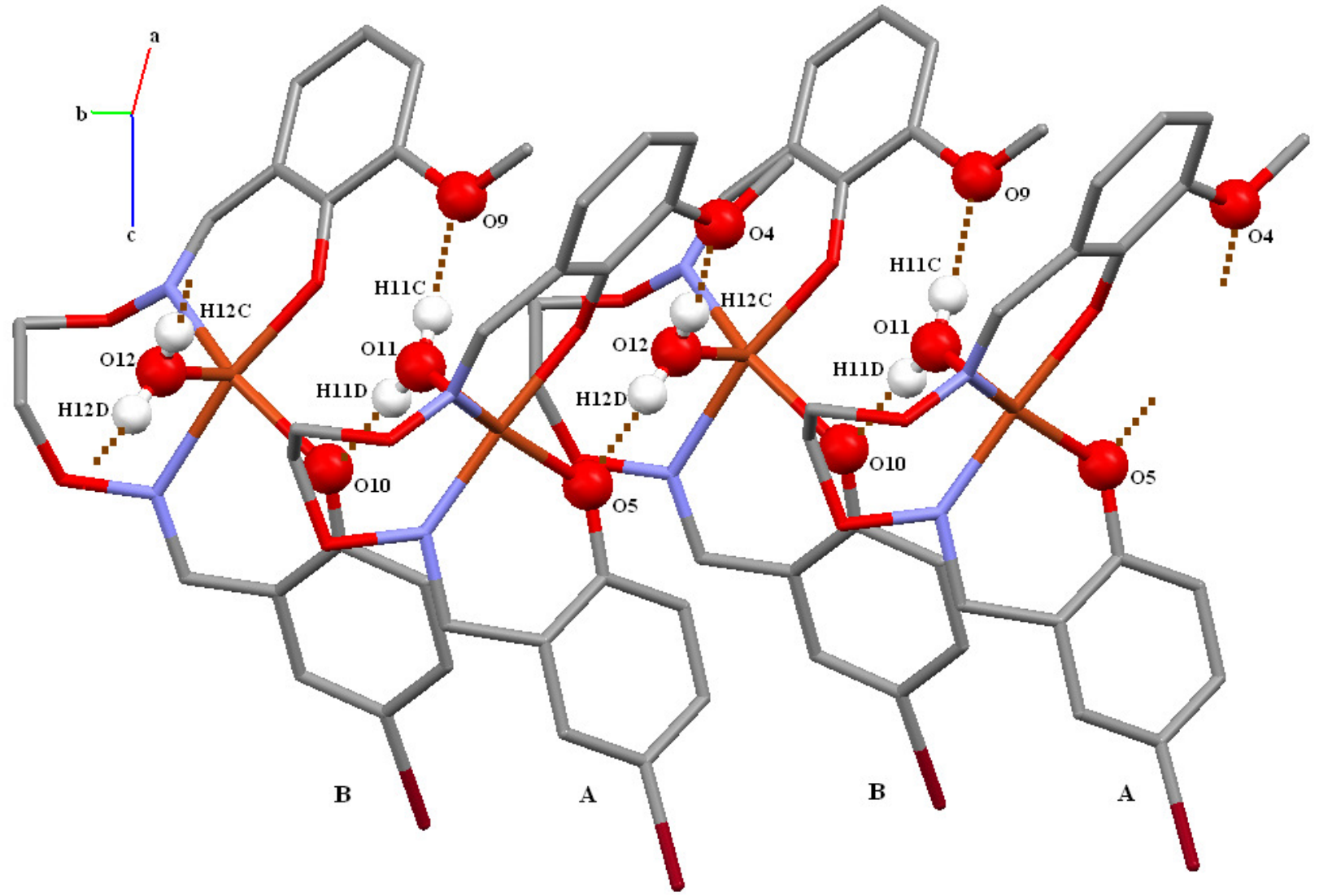

Fig. 2. Part of the infinite 1D chain motif of the complex. (Hydrogen atoms, except those forming hydrogen bonds, are omitted for clarity

In the crystal structure, molecule $\mathrm{A}$ and molecules $\mathrm{B}$ interlink each other into a 1D infinite chain (Fig. 2) through four strong intermolecular O12-H12C‥ $04, \mathrm{O} 12-\mathrm{H} 12 \mathrm{D} \cdots \mathrm{O} 5$,

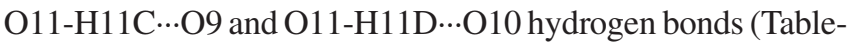
3). The packing diagram of the complex also shows an infinite regular network structure along the a axis and form a centrosymmetric rectangle-like large cave structure via carbon, oxygen, bromine and copper atoms along the a axis of the unit cell ${ }^{1-13}$.

\begin{tabular}{|c|c|c|c|c|}
\hline \multicolumn{5}{|c|}{$\begin{array}{c}\text { TABLE-3 } \\
\text { HYDROGEN BONDS }\left[\AA{ }^{\circ}\right] \text { FOR THE COMPLEX }\end{array}$} \\
\hline D-H $\cdots A$ & $d(D-H)$ & $\mathrm{d}(\mathrm{H} \cdots \mathrm{A})$ & $\angle \mathrm{DHA}$ & $d(D \cdots A)$ \\
\hline O11-H11C‥O99 & 0.85 & 1.95 & 179 & $2.801(4)$ \\
\hline O11-H11D $\cdots \mathrm{O} 10$ & 0.85 & 1.93 & 179 & $2.782(4)$ \\
\hline $\mathrm{O} 12-\mathrm{H} 12 \mathrm{C} \cdots \mathrm{O} 4$ & 0.85 & 2.02 & 177 & $2.872(4)$ \\
\hline 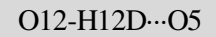 & 0.85 & 1.87 & 174 & $2.714(4)$ \\
\hline
\end{tabular}

\section{REFERENCES}

1. W.K. Dong, J.G. Duan, Y.H. Guan, J.Y. Shi and C.Y. Zhao, Inorg. Chim. Acta, 362, 1129 (2009).

2. W.K. Dong, X.N. He, H.B. Yan, Z.W. Lv, X. Chen, C.Y. Zhao and X.L. Tang, Polyhedron, 28, 1419 (2009).
3. M.A. Subhan, T. Suzuki and S. Kaizaki, J. Chem. Soc., 1416 (2002).

4. W.K. Dong, Y.X. Sun, Y.P. Zhang, L. Li, X.N. He and X.L. Tang, Inorg. Chim. Acta, 362, 117 (2009).

5. W.K. Dong, Y.X. Sun, S.J. Xing, Y. Wang and X.H. Gao, Z. Naturforsch., 67b, 197 (2012).

6. A. Bencini, C. Benelli, A. Caneschi, R.L. Carlin, A. Dei and D. Gatteschi, J. Am. Chem. Soc., 107, 8128 (1985).

7. W.K. Dong and J.G. Duan, J. Coord. Chem., 61, 781 (2007).

8. M. Sasaki, K. Manseki, H. Horiuchi, M. Kumagai and H. Okawa, J. Chem. Soc., 259 (2000).

9. I. Sasaki, D. Pujol and A. Gaudemer, Inorg. Chim. Acta, 134, 53 (1987).

10. W.K. Dong, J.F. Tong, Y.X. Sun, S.S. Gong and L. Li, Synth. React. Inorg. Met.-Org. Nano-Met. Chem., 41, 155 (2011).

11. H.L. Wu, X.C. Huang, J.K. Yuan, F. Kou, F. Jia, B. Liu and Y. Bai, Z. Naturforsch., 66b, 1049 (2011).

12. W.K. Dong, G. Wang, S.S. Gong, J.F. Tong, Y.X. Sun and X.H. Gao, Transition Met. Chem., 37, 271 (2012).

13. W.K. Dong, X.N. He, C.M. Dong, L. Wang, J.K. Zhong, X. Chen and T.Z. Yu, Z. Kristallogr. New Cryst. Struct., 222, 289 (2007). 